\title{
Evaluation of T and B lymphocytes in liver infiltrates of patients with chronic active hepatitis
}

\author{
SILVIA FARGION, GABRIELE SANGALLI, GUIDO RONCHI, AND \\ GEMINO FIORELLI
}

From the Istituto di Clinica Medica III, Università degli Studi-Milano, via Pace 15, 20122 Milan, Italy

SUMMARY The proportions of $\mathrm{T}$ and $\mathrm{B}$ lymphocytes in the liver infiltrates of 23 patients with chronic active hepatitis have been determined. The results were compared with the values obtained from peripheral blood and with the presence of $\mathrm{HB}$ virus markers and alpha-fetoprotein in liver tissue. A group of patients with chronic liver disease other than chronic active hepatitis were studied as controls. In chronic active hepatitis the percentage of hepatic $\mathrm{T}$ cells was $49 \pm 8 \mathrm{SD}$ (control patients $61 \pm 8)(\mathrm{P}<0.01)$, whereas the percentage of B cells was $40 \pm 10$ (control patients $18 \pm 8$ ) $(\mathrm{P}<0.01)$.

No correlation was observed between hepatic $T$ and $B$ cells and the presence of $H B$ virus. The numbers of $\mathrm{T}$ cells in liver tissue were significantly higher, the numbers of $\mathrm{B}$ cells lower, in patients whose biopsies were positive for alpha-fetoprotein than in those whose biopsies were negative. In peripheral blood, only the patients with chronic active hepatitis and established cirrhosis presented lower absolute values of $\mathrm{T}$ cells, whereas surface immunoglobulin-positive lymphocytes were within the normal range.

There have been conflicting reports on the proportions of $\mathbf{T}$ and $\mathrm{B}$ lymphocytes in the blood of patients with chronic active hepatitis (CAH). Sposito et al. (1974) and Galili et al. (1975) found normal values, whereas DeHoratius et al. (1974) and Thomas et al. (1976) showed a significant reduction in the absolute and relative numbers of $T$ cells. These discrepancies might be related either to the variable effects of liver lymphoid infiltrates (Bernstein et al., 1974) or to the presence of conditions such as cirrhosis and splenomegaly which have not been adequately considered by the investigators.

To gain more direct information on $T$ and $B$ lymphocytes in $\mathrm{CAH}$, we examined their proportions in the liver infiltrates of 23 patients and related them to those in blood and to the presence of hepatitis B virus (HBV) markers and alphafetoprotein (AFP), since they are thought to modify $T$ and B lymphocyte proportions (Gupta and Siegal, 1975; Strelkauskas et al., 1975) in liver tissue. The relationship to cirrhosis and splenomegaly has also been assessed. A group of patients with chronic liver disease other than CAH, in whose biopsy specimens lymphocytic infiltrates were present, were studied as controls.

Received for publication 23 October 1978

\section{Material and methods}

PATIENTS

Seventy patients with chronic liver disease were studied: 34 had CAH without cirrhosis, $28 \mathrm{CAH}$ and established cirrhosis, five chronic persistent hepatitis, and three inactive alcoholic cirrhosis. In all the patients the diagnosis was based on clinical, biochemical, and histological findings. Laparoscopy was performed in 34 patients with CAH without cirrhosis, in nine patients with CAH and cirrhosis, and in three patients with alcoholic cirrhosis. Frank splenomegaly was present in six patients with CAH without cirrhosis and in 22 patients with CAH and cirrhosis. Normal controls were 23 healthy laboratory workers (Table 1).

\section{PERIPHERAL BLOOD STUDIES}

Peripheral blood lymphocytes (PBL) were separated from heparinised venous blood by the FicollHypaque gradient method, according to Böyum (1968). The adherent cells were removed by a 45 minute incubation in a Petri dish in Hanks' balanced salt solution (HBSS) containing $50 \%$ fetal calf serum (FCS) in $5 \% \mathrm{CO}_{2}$ atmosphere at $37^{\circ} \mathrm{C}$. The monocyte contamination in the final suspension was $2-4 \%$, as assessed morphologically. Surface immuno- 
Table 1 Age range and sex distribution of patients and controls

\begin{tabular}{lllll}
\hline Diagnosis & \multicolumn{2}{l}{ Number of subjects } & $\begin{array}{c}\text { Age range } \\
\text { (mean age) }\end{array}$ \\
\cline { 2 - 4 } & Total & Male & Female & \\
\hline $\begin{array}{l}\text { Chronic active } \\
\text { hepatitis }\end{array}$ & & & & \\
$\begin{array}{l}\text { Without cirrhosis } \\
\text { With cirrhosis }\end{array}$ & 28 & 12 & 16 & $20-54(39)$ \\
$\begin{array}{l}\text { Chronic persistent } \\
\text { hepatitis }\end{array}$ & 5 & 19 & 15 & $26-58(41)$ \\
$\begin{array}{l}\text { Alcoholic cirrhosis } \\
\text { Controls }\end{array}$ & 3 & 3 & 2 & $18-36(26)$ \\
\hline
\end{tabular}

globulin (SIg) positive lymphocytes were determined by a standard direct immunofluorescent technique (Pernis et al., 1970) using purified rabbit antihuman immunoglobulin antiserum centrifuged at $30000 \mathrm{~g}$ for 30 minutes before use. Normal human as well as rabbit immunoglobulin fluorescein isothiocyanate were used as controls. Briefly, $50 \mu \mathrm{l}$ of a $20 \times 10^{6} / \mathrm{ml}$ lymphocyte suspension in HBSS were mixed with $50 \mu$ l of the antiserum, incubated for 30 minutes on ice, and washed three times in HBSS.

In a smaller number of cases the lymphocytes bearing $\mathrm{C}_{3}$ receptor were identified by erythrocyteantibody-complement (EAC) rosettes, according to Bianco et al. (1970); $100 \mu \mathrm{l}$ of sheep red blood cells (SRBC) coated with $19 \mathrm{~S}$ antibody against SRBC (IgM) and fresh human serum as a source of complement were mixed with $100 \mu \mathrm{l}$ of lymphocyte suspension $\left(5 \times 10^{6} / \mathrm{ml}\right)$. The mixture was incubated at $37^{\circ} \mathrm{C}$ for 30 minutes and centrifuged at $200 \mathrm{~g}$ for 5 minutes and then incubated at $37^{\circ} \mathrm{C}$ for 15 minutes.

$T$ lymphocytes were identified by the sheep erythrocyte binding technique after incubation at $4^{\circ} \mathrm{C}$ overnight; $100 \mu \mathrm{l}$ of a $4 \times 10^{6} / \mathrm{ml}$ lymphocyte suspension were mixed with $100 \mu \mathrm{l}$ of a $12 \times 10^{5} / \mathrm{ml}$ SRBC suspension, incubated for 5 minutes at $37^{\circ} \mathrm{C}$, then centrifuged for 5 minutes at $200 \mathrm{~g}$, and finally incubated at $4^{\circ} \mathrm{C}$ overnight (Fröland, 1972).

Absolute numbers of the blood lymphocyte subpopulations were estimated from the total lymphocyte count.

\section{LIVER BIOPSY STUDIES}

The liver biopsy specimens were divided into two parts, one of which was fixed in Bouin's solution and stained with haematoxylin and eosin for histology and the other snap-frozen in an isopentane dry ice mixture. Frozen specimens were embedded in OCT compound (Ames Co, Elkart, Indiana, USA), and serial sections of 5 micron thickness were cut on a cryostat. Lymphocytic infiltrates were evaluated by haematoxylin-eosin stainings. Nonlymphocytic cells in the inflammatory infiltrate were evaluated by non-specific esterase staining (Yam et al., 1971). The proportions of $\mathrm{T}$ and $\mathrm{B}$ cells were estimated by three observers on neighbouring sections; 600 to 800 lymphocytes were counted in each specimen in order to reduce to the minimum the possibility of sampling errors due to the variation in the distribution of inflammatory cells in the tissues. $T$ cells were identified by indirect immunofluorescence using heat-inactivated rabbit anti-human T-cell serum, prepared from lymphocytes from a patient with Bruton's agammaglobulinaemia. (The antiserum was kindly supplied by Professor Aiuti, University of Rome). Fluoresceinated goat anti-rabbit IgG (Behringwerke), previously absorbed with human immunoglobulin, dialysed against phosphate buffered saline (PBS), pH 7.3, $0.01 \mathrm{M}$, and centrifuged at $30000 \mathrm{~g}$ for 30 minutes, was used for indirect staining.

Before use the anti-T-cell serum was absorbed with B lymphocytes $\left(8 \times 10^{7}\right.$ cells $\left./ \mathrm{ml}\right)$ from eight patients with chronic lymphatic leukaemia (CLL) for 30 minutes at $37^{\circ} \mathrm{C}$. Further absorptions were undertaken with acetone liver powder, twice with normal Rhesus-positive human red cells $\left(5 \times 10^{8}\right.$ cells $/ \mathrm{ml}$ ), and twice with polymorphonuclear leucocytes $\left(15 \times 10^{6}\right.$ cells $\left./ \mathrm{ml}\right)$. After the absorptions the antiserum was ultracentrifuged at $30000 \mathrm{~g}$ for 30 minutes. As a control the anti-T-cell serum was tested with lymphocytes from normal subjects and from patients with CLL. The percentage of normal lymphocytes stained with the anti-T serum was $70 \pm 8$ and CLL lymphocytes $9 \pm 6$.

$B$ cells were identified by a modification of the EAC technique of Tannenbaum et al. (1975). Briefly, sections were air-dried for 30 minutes at room temperature, washed three times in PBS, and overlaid for 30 minutes at $37^{\circ} \mathrm{C}$ with SRBC sensitised with 19S (IgM) antibodies against SRBC (diluted 1/2000 in HBSS) (Cordis Laboratories, Miami, Florida, USA) and human fresh serum as a source of complement (diluted $1 / 20$ in HBSS). After incubation the slides were exhaustively washed in PBS, fixed with $3 \%$ glutaraldehyde, and stained with haematoxylin and eosin. The controls for the EAC rosettes were normal PBL (normal values $21 \pm 6 \%$ ). Additional controls were performed incubating erythrocyte-antibody (IgM 19 S) on the tissue sections in the absence of complement.

Control sections from normal human lymph node, where anti-T serum stained paracortical areas and EAC rosettes follicular areas, were used (Fig. 1 a-d). AFP was identified in liver cells by indirect immunofluorescence, using a rabbit antiserum to human AFP, diluted 1/4 in PBS (Behringwerke) (Fig. 2).

Hepatitis B surface antigen (HBsAg) was detected 

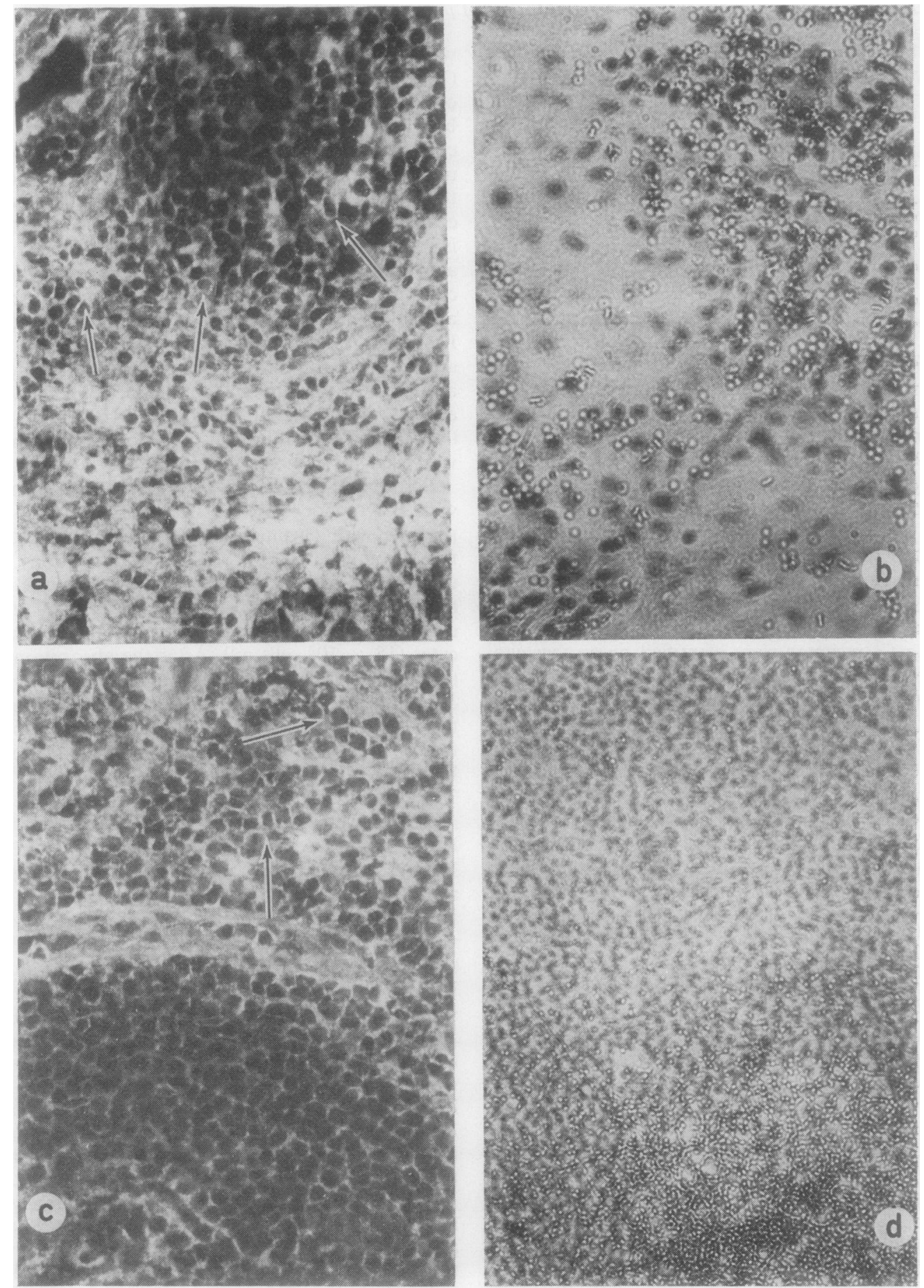

Fig. 1 (a) Section of liver treated with an anti-T lymphocyte serum (indirect immunofluorescence). The arrow indicates T lymphocytes. $(\times 450)$; (b) Section of liver treated with EAC. In the lymphocytic infiltrate some lymphocytes surrounded by EAC rosettes are evident. ( $\times 450)$; (c) Section of lymph node treated with an anti-T lymphocyte serum. T lymphocytes are evident outside the follicular area (arrow). $(\times 450)$; (d) Section of lymph node treated with EAC. Erythrocytes are present in the germinal centre and in the follicular area. $(\times 150)$. 


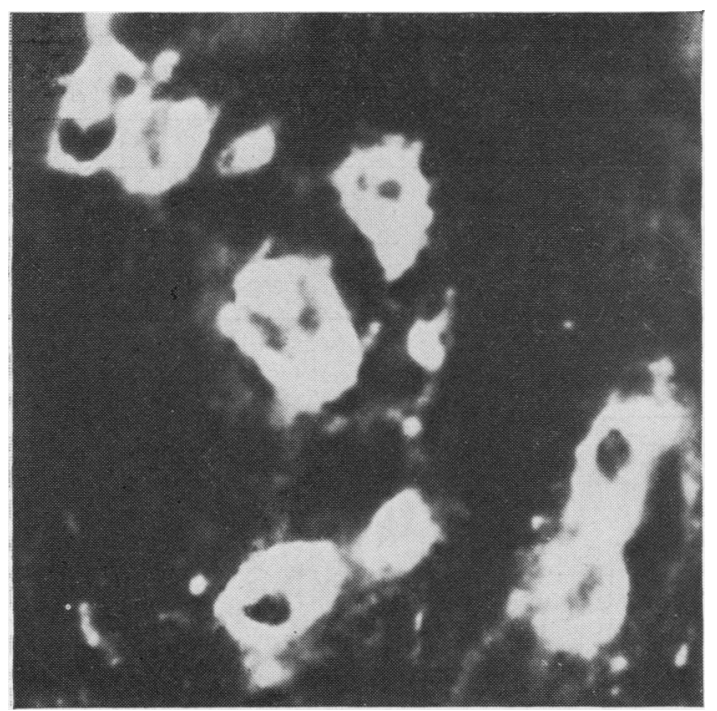

Fig. 2 Section of liver treated with an anti-AFP serum (indirect immunofluorescence): scattered AFPpositive hepatocytes are evident. $(\times 450)$

in the liver by indirect immunofluorescence using a horse antiserum to HBsAg diluted 1/2 (Wellcome) (Fig. 3). Control slides were overlaid with normal human serum and PBS to confirm the specificity of AFP and HBsAg stainings.

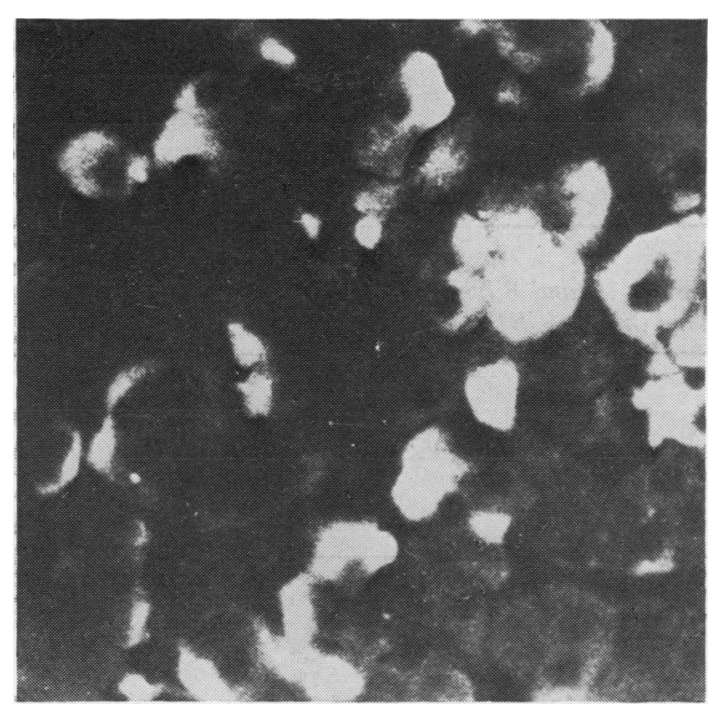

Fig. 3 Section of liver treated with an anti-HBs Ag serum (indirect immunofluorescence): $\mathrm{HBsAg}$ fluorescence is present in the cytoplasm of numerous hepatocytes. $(\times 450)$
SERUM STUDIES

AFP levels were determined by radioimmunoassay (Abbott AFP RIA kit) using the standards furnished by the kit. HBsAg was detected by radioimmunoassay (Abbott AusRIA II) and hepatitis B core antibody (HBcAb) by indirect immunofluorescence, testing patients' sera with liver sections from a core-positive patient who had died with acute fulminant hepatitis.

STATISTICAL EVALUATIONS

The statistical significance was calculated by the non-parametric test of Mann-Whitney.

\section{Results}

PERIPHERAL BLOOD

The number and percentage of $T$ lymphocytes in the blood were significantly reduced only in patients with CAH and cirrhosis (Table 2). No difference in lymphocyte subpopulations was observed when HBsAg or abnormal serum levels of AFP were present.

\section{LIVER TISSUE}

In the biopsy tissue from 19 patients lymphocytic infiltration was graded as severe and in four patients as moderate. The specimens from control patients demonstrated an infiltration that ranged from moderate to severe. In $\mathrm{CAH}$ without and with cirrhosis, the proportion of $\mathbf{T}$ cells in the infiltrates was lower $(49 \pm 8)$ than in the group of patients with other forms of chronic liver disease $(61 \pm 8)$ $(P<0.01)$, whereas the number of $B$ cells was significantly higher $(\mathrm{CAH}, 40 \pm 10$; other chronic liver disease, $18 \pm 8)(P<0.01)$ (Fig. 4).

As shown in Fig. 5, in CAH without cirrhosis $\mathrm{T}$ and $B$ lymphocytes were present in the infiltrates in similar proportions $(\mathrm{T}, 42 \pm 12 ; \mathrm{B}, 43 \pm 12)$, while in CAH with cirrhosis the values of $\mathrm{T}$ cells were higher than those of $B$ cells $(T, 54 \pm 9$; $B, 36 \pm 10)$. The proportions of $T$ cells in the two groups were significantly different $(P<0.01)$.

A negative linear correlation between the percentages of $T$ cells in the liver infiltrates and the number of $T$ lymphocytes in blood was seen ( $P<0.01$ ) (Fig. 6).

No correlation was observed between $T$ and $B$ lymphocytes in the infiltrates and the presence of HBsAg in the tissue (Table 3).

In six patients with CAH and AFP-positive cells, the proportion of liver T-lymphocytes was higher $(59 \pm 7)$ and that of B-lymphocytes lower $(29 \pm 6)$ compared with CAH patients with AFPnegative cells (Table 4). 
Table 2 Peripheral blood lymphocytes in chronic liver disease (mean $\pm S D$ )

\begin{tabular}{|c|c|c|c|c|c|c|c|c|}
\hline & \multirow{2}{*}{$\begin{array}{l}\text { No. of } \\
\text { cases }\end{array}$} & \multicolumn{2}{|l|}{$E$ rosettes } & \multicolumn{2}{|c|}{ SIg bearing lymphocytes } & \multirow{2}{*}{$\begin{array}{l}\text { No. of } \\
\text { cases }\end{array}$} & \multicolumn{2}{|c|}{$E A C$ rosettes } \\
\hline & & $\%$ & Cells $/ \mathrm{mm}^{3}$ & $\%$ & Cells $/ \mathrm{mm}^{3}$ & & $\%$ & Cells $/ \mathrm{mm}^{3}$ \\
\hline \multicolumn{9}{|l|}{ Chronic active hepatitis } \\
\hline Without cirrhosis & 28 & $56 \pm 9$ & $1484 \pm 545$ & $22 \pm 4$ & $582 \pm 136$ & 15 & $27 \pm 6$ & $603 \pm 97$ \\
\hline With cirrhosis & 34 & $54 \pm 9^{*}$ & $1127 \pm 523 \dagger$ & $23 \pm 8$ & $487 \pm 89$ & 20 & $24 \pm 7$ & $511 \pm 118$ \\
\hline Chronic persistent hepatitis & 5 & $58 \pm 6$ & $1470 \pm 427$ & $24 \pm 6$ & $588 \pm 240$ & - & - & - \\
\hline Controls & 23 & $60 \pm 9^{*}$ & $1431 \pm 369$ & $23 \pm 5$ & $471 \pm 179$ & 15 & $26 \pm 4$ & $528 \pm 127$ \\
\hline
\end{tabular}

$*_{\mathrm{P}}<0.05$

$\dagger_{\mathrm{P}}<0.01$ when compared with $\mathrm{CAH}$ without cirrhosis and controls

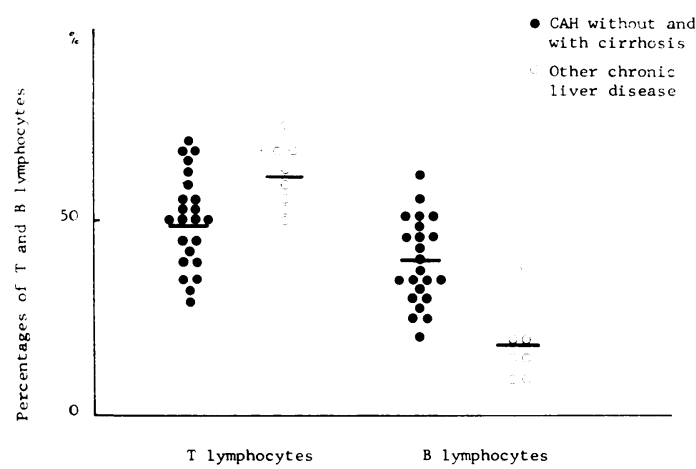

Fig. $4 T$ and $B$ lymphocytes in liver tissue of patients with chronic liver disease.

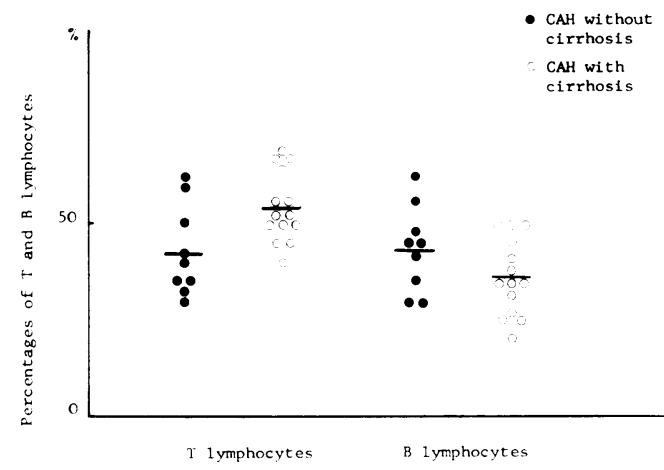

Fig. $5 T$ and $B$ lymphocytes in liver tissue of patients with $\mathrm{CAH}$.

\section{Discussion}

A significant decrease of blood $\mathrm{T}$ cells was detected in patients with $\mathrm{CAH}$ only when frank cirrhosis was present, whereas lymphocytes detected by SIg were within the normal limits in all groups of patients tested. The technique used identified at least two populations of circulating lymphocytes on which

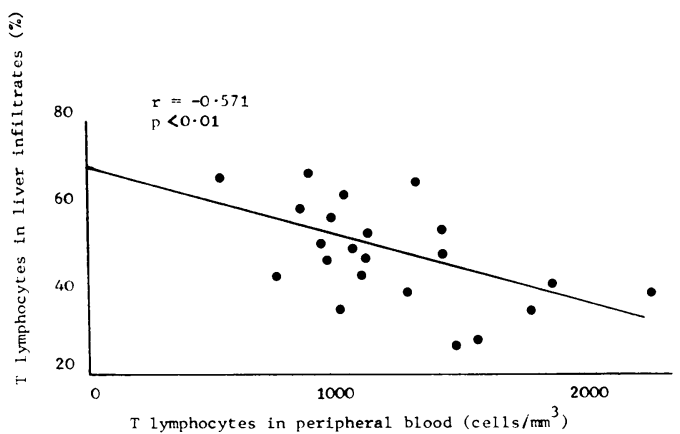

Fig. 6 Correlation between percentages of $T$ lymphocytes in liver infiltrates and number of $T$ cells in peripheral blood in $C A H$.

Table 3 T and B lymphocytes and HBsAg in liver tissue (mean $\pm S D)$

\begin{tabular}{llll}
\hline & $\begin{array}{l}\text { No. of } \\
\text { cases }\end{array}$ & \multicolumn{2}{l}{ Liver } \\
\cline { 3 - 4 } & & $T \%$ & $B \%$ \\
\hline $\begin{array}{l}\text { Chronic active hepatitis: } \\
\text { HBsAg positive }\end{array}$ & 9 & $51 \pm 12$ & $41 \pm 12$ \\
HBsAg negative & 14 & $41 \pm 12$ & $36 \pm 12$ \\
\hline
\end{tabular}

Table $4 \quad T$ and $B$ lymphocytes and $A F P$ in liver tissue (mean $\pm S D)$

\begin{tabular}{llll}
\hline & No. of \\
& cases & \multicolumn{2}{l}{ Liver } \\
\cline { 3 - 4 } & & $T \%$ & $B \%$ \\
\hline $\begin{array}{l}\text { Chronic active hepatitis: } \\
\text { AFP positive }\end{array}$ & 6 & $59 \pm 7 *$ & $29 \pm 6+$ \\
AFP negative & 17 & $46 \pm 10^{*} 42 \pm 9+$ \\
\hline
\end{tabular}

$*_{\mathbf{P}}<0.05$

$\dagger \mathbf{P}<0.05$

immunoglobulins can be detected: B cells with membrane-incorporated immunoglobulins and $\mathrm{K}$ cells that lack membrane-incorporated immunoglobulins but have a receptor for membrane-labile 
cytophilic immunoglobulins (Lobo and Horwitz, 1976; Alexander and Sanders, 1977). Normal $\mathrm{B}+\mathrm{K}$-cell concentrations in patients with $\mathrm{CAH}$ were also noted by Thomas et al. (1976) using an EA rosette technique. From these results it is impossible to say if normal $\mathrm{B}+\mathrm{K}$ values hide abnormal values of the single subpopulations. The finding of a decreased number of $\mathrm{T}$ cells in the patients with CAH and cirrhosis may account for the conflicting reports by different authors (DeHoratius et al., 1974; Sposito et al., 1974; Galili et al., 1975; Thomas et al., 1976; Miller et al., 1977) as no distinction has been made in the various series between groups of patients with or without cirrhosis. Another possible explanation of the higher numbers of T cells in patients with CAH without cirrhosis is that FCS (that contains thymosin) used to remove monocytes may convert null cells into $T$ cells, as shown by Thomas et al. (1976), even if it is difficult to explain why thymosin should act differently on the T-lymphocytes of patients with $\mathrm{CAH}$ in respect to the presence or absence of cirrhosis.

$T$ and $B$ lymphocytes were present in similar proportions in the liver infiltrates of patients with CAH considered as a whole, while patients with chronic persistent hepatitis had a higher proportion of $\mathrm{T}$ cells in both the liver infiltrate and peripheral blood. It is possible that a small error in the evaluation is due to the variation in the distribution of inflammatory cells in the tissue, even if the high number of lymphocytes evaluated in each biopsy specimen makes this possibility improbable. Although the number of patients with chronic persistent hepatitis is low, these results suggest that in chronic persistent hepatitis blood lymphocytes infiltrate the liver in the same T:B ratio as in blood, suggesting that lymphocyte subpopulations are not specifically sensitised to some liver or foreign antigens. Husby et al. (1975), in three patients with chronic persistent hepatitis, reported hepatic $T$ and $B$ proportions similar to those found in our cases, whereas of the two patients with $\mathrm{CAH}$ examined, the first had $50 \%$ each of $\mathrm{T}$ and $\mathrm{B}$ cells, and the second $30 \% \mathrm{~T}$ cells and $70 \% \mathrm{~B}$ cells. Our results in patients with CAH are in agreement with those of Sposito et al. (1974), who identified T and B lymphocytes from liver biopsy suspensions from six patients with CAH by the technique of Ficoll gradient separation. By contrast, Miller et al. (1977), in a group of patients submitted to haemodialysis with HBsAg-positive acute and chronic hepatitis, reported a marked predominance of $T$ cells in the hepatic infiltrates. A different selection of patients, and different methods, could explain these discrepancies. Methodological differences also make it difficult to compare our results with those of
Sanchez-Tapias et al. (1977). In our series of 23 patients with $\mathrm{CAH}$, we have detected a significantly higher percentage of $T$ cells and a slightly lower percentage of $B$ cells in the liver when a clear, cirrhotic picture was present compared with the group without apparent cirrhosis. This agrees with the finding of the few patients with alcoholic cirrhosis included in our study and with the results observed by Husby et al. (1975) in a larger series. Several mechanisms may explain the influence of cirrhosis on the alterations of lymphocyte subpopulations. One of these may be related to the more severe portal hypertension and splenomegaly with the possible sequestration of $\mathrm{T}$ lymphocytes, as proposed by Thomas et al. (1976). Local factors causing a sensitisation of the lymphocytes to liverspecific antigens may lead to hepatic entrapping of lymphocytes. The negative correlation between hepatic and blood lymphocytes observed in our patients with cirrhosis supports this view.

Murgita and Tomasi $(1975 \mathrm{a}, \mathrm{b})$ have suggested that the increased concentration of AFP in regenerating hepatocytes may determine local immunosuppression, which in turn could modify $T$ and $B$ proportions in the liver. Moreover, the possibility that cells homing to the liver may be increased by a specific linkage with AFP is suggested by the findings of Dattwyler et al. (1975) that murine T cells have a surface receptor for AFP. The role of AFP in liver disease has recently been supported by Keller $e t$ al. (1976), who described the presence of AFP on the surface of blood $T$ lymphocytes and a negative correlation between AFP-positive lymphocytes and the number of $\mathrm{T}$ cells in the blood of patients with CAH.

Lastly, although many authors (Dudley et al., 1972; DeHoratius et al., 1974; Thomas et al., 1975; Paronetto and Vernace, 1975) have proposed a relationship between $T$ and $B$ lymphocytes and HB virus, in this study we have failed to demonstrate any correlation. The discrepancy might be related to differences in the selection of patients and especially to the presence of cirrhosis, the relevance of which has been emphasised by this investigation.

\section{References}

Alexander, E. L., and Sanders, S. K. (1977). F(ab) reagents are not required if goat, rather than rabbit, antibodies are used to detect human surface immunoglobulins. Journal of Immunology, 119, 1084-1088.

Bernstein, I. M., Webster, K. H., Williams, R. C., Jr., and Strickland, R. G. (1974). Reduction in circulating $T$ lymphocytes in alcoholic liver disease. Lancet, 2 , 488-490.

Bianco, C., Patrick, R., and Nussenzweig, V. (1970). 
A population of lymphocytes bearing a membrane receptor for antigen-antibody-complement complexes. I. Separation and characterization. Journal of Experimental Medicine, 132, 702-720.

Böyum, A. (1968). Isolation of mononuclear cells and granulocytes from human blood. Scandinavian Journal of Clinical Laboratory Investigation, 21, Suppl 97, 77-89.

Dattwyler, R., Murgita, R. A., and Tomasi, T. B., Jr. (1975). Binding of alpha-fetoprotein to murine $T$ cells. Nature, 256, 656-657.

DeHoratius, R. J., Strickland, R. G., and Williams, R. C., Jr. (1974). T and B lymphocytes in acute and chronic hepatitis. Clinical Immunology and Immunopathology, 2, 353-360.

Dudley, F. J., Fox, R. A., and Sherlock, S. (1972). Cellular immunity and hepatitis-associated Australia antigen liver disease. Lancet, 1, 723-726.

Fröland, S. S. (1972). Binding of sheep erythrocytes to human lymphocytes. A probable marker of T lymphocytes. Scandinavian Journal of Immunology, 1, 269-280.

Galili, U., Eliakim, M., Slavin, S., and Schlesinger, M. (1975). Lymphocyte subpopulations in chronic active hepatitis: increase in lymphocytes forming stable $\mathrm{E}$ rosettes. Clinical Immunology and Immunopathology, 4, 538-544.

Gupta, S., and Siegal, F. P. (1975). In vitro inhibition of $\mathrm{E}$ rosettes with human amniotic fluid (Letter). New England Journal of Medicine, 293, 302-303.

Husby, G., Strickland, R. G., Caldwell, J. L., and Williams, R. C., Jr. (1975). Localization of T and B cells and alpha-fetoprotein in hepatic biopsies from patients with liver disease. Journal of Clinical Investigation, 56, 1198-1209.

Keller, R. H., Summerskill, W. H. J., Geubel, A. P., Shorter, R. G., and Tomasi, T. B. (1976). Alphafe oprotein and suppression of cell mediated immunity int chronic active liver disease (CALD) (Abstract). Gastroenterology, 70, 901.

Lobo, P. I., and Horwitz, D. A. (1976). An appraisal of Fc receptors on human peripheral blood B and L lymphocytes. Journal of Immunology, 117, 939-943.

Miller, D. J., Dwyer, J. M., and Klatskin, G. (1977). Identification of lymphocytes in percutaneous liver biopsy cores: different $\mathrm{T}: \mathrm{B}$ cell ratio in $\mathrm{HBs} \mathbf{A g}$ positive and negative hepatitis. Gastroenterology, 72, 1199-1203.

Murgita, R. A., and Tomasi, T. B., Jr. (1975a). Suppression of the immune response by alpha-fetoprotein. I.
The effect of mouse alpha-fetoprotein on the primary and secondary antibody response. Journal of Experimental Medicine, 141, 269-286.

Murgita, R. A., and Tomasi, T. B., Jr. (1975b). Suppression of the immune response by alpha-fetoprotein. II. The effect of mouse alpha-fetoprotein on mixed lymphocyte reactivity and mitogen-induced lymphocyte transformation. Journal of Experimental Medicine, 141, 440-452.

Paronetto, F., and Vernace, S. (1975). Immunological studies in patients with chronic active hepatitis. Cytotoxic activity of lymphocytes to autochthonous liver cells grown in tissue culture. Clinical and Experimental Immunology, 19, 99-104.

Pernis, B., Forni, L., and Amante, L. (1970). Immunoglobulin spots on the surface of rabbit lymphocyte. Journal of Experimental Medicine, 132, 1001-1017.

Sanchez-Tapias, J., Thomas, H. C., and Sherlock, S. (1977). Lymphocyte populations in liver biopsy specimens from patients with chronic liver disease. Gut, 18, 472-475.

Sposito, M., Aiuti, F., Capocaccia, L., Panichi, G., and Ciarla, M. V. (1974). TDL and BDL in peripheral blood and in liver tissue in acute and chronic hepatitis (Abstract). Digestion, 10, 327-328.

Strelkauskas, A. J., Wilson, B. S., and Dray, S. (1975). Inversion of levels of human $\mathbf{T}$ and $\mathbf{B}$ cells in early pregnancy. Nature, 258, 331-332.

Tannenbaum, H., Pinkus, G. S., Anderson, L. G., and Schur, P. H. (1975). Immunological characterization of the mononuclear cell infiltrates in rheumatoid synovia, in rheumatoid nodules and in lip biopsies from patients with Sjögren's syndrome. Arthritis and Rheumatism, 18, 305-314.

Thomas, H. C., Freni, M., Sanchez-Tapias, J., De Villiers, D., Jain, S., and Sherlock, S. (1976). Peripheral blood lymphocyte populations in chronic liver disease. Clinical and Experimental Immunology, 26, 222-227.

Thomas, H. C., Freni, M., Sanchez-Tapias, J., Jain, S., and Sherlock, S. (1975). Lymphocyte populations in chronic liver disease (Abstract). Digestion, 12, 354-355.

Yam, L. T., Li, C. Y., and Crosby, W. H. (1971). Cytochemical identification of monocytes and granulocytes. American Journal of Clinical Pathology, 55, 283-290.

Requests for reprints to: Dr Silvia Fargion, Istituto di Clinica Medica III, Università degli Studi-Milano, via Pace 15, 20122 Milan, Italy. 